\title{
O ROLI POLSKIEJ MUZYKI W KSZTALTOWANIU TOŻSAMOŚCI NARODOWEJ
}

\author{
ON THE INFLUENCE OF POLISH MUSIC \\ ON NATIONAL IDENTITY
}

\begin{abstract}
The article deals with the role of patriotic songs in shaping national identity of the Polish. The discourse is divided into three matters. The first part is introductory and treats about the most essential issues and research problems, regarding the key topic. I attempt to answer the raised questions in the last part of the work. The middle part of a historical character presents crucial research assumptions, along with all the transformations that have taken place over the years, and have been influencing our comprehending of national songs and strengthening the feeling of national identity. The final part sums the discourse up and is critical to the key topic. I strive to foresee possible consequences of the described phenomena. I derive my conclusions from the analysis, presented in the second part of the article, and from my personal experience, which has been gained due to long years of participating and organizing patriotic concerts and performances.
\end{abstract}

Key words: national identity; music; patriotism; patriotic songs; national culture; national symbols

\section{STRESZCZENIE}

W poniższym artykule zajmuję się rozważaniami na temat współczesnej roli pieśni patriotycznej w kształtowaniu tożsamości narodowej Polaków. Artykuł został podzielony na trzy

This is an Open Access article distributed under the terms of the Creative Commons Attribution 3.0 PL License (creativecommons.org/licenses/by/3.0/pl/), which permits redistribution, commercial and non-commercial, provided that the article is properly cited. (C) The Author(s) 2014.

Publisher: Institute of Slavic Studies PAS [Wydawca: Instytut Slawistyki PAN] 
części. Pierwsza z nich ma charakter wprowadzający i przedstawia najważniejsze problemy badawcze dotyczące tematu. Druga część ma charakter historyczny, przedstawia najistotniejsze założenia badaczy oraz przemiany na przestrzeni lat naszego rozumienia znaczenia pieśni patriotycznych w kształtowaniu i umacnianiu polskiej tożsamości narodowej. Ostatnia część stanowi próbę przewidzenia przyszłych następstw analizowanego problemu. Przedstawione wnioski opierają się na analizie oraz obserwacjach własnych wynikających z wielu lat uczestniczenia, organizowania i tworzenia koncertów o charakterze patriotycznym.

Słowa kluczowe: tożsamość narodowa; muzyka; patriotyzm; pieśń patriotyczna; styl narodowy; kultura narodowa; symbole narodowe

ROLA PIEŚNI I PIOSENEK WSPÓLCZEŚNIE

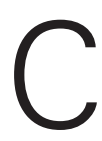

zy obecnie rola polskiej pieśni patriotycznej jest taka sama jak przed laty? Jakie są konsekwencje procesów globalizacyjnych na gruncie muzyki ? Czy tożsamość narodowa jest dziś zagrożona? Czy można i trzeba jej bronić?

Jesteśmy świadkami procesów globalizacyjnych na gruncie ekonomii, polityki, integracji europejskiej i niebywałej mobilności ludzkiej. Następuje zarazem kosmopolityzacja kultury, wszystkich dziedzin sztuki, również muzyki popularnej. Powstaje pytanie - czy globalizacyjne tendencje, które są zauważalne w handlu, produkcji, przepływie finansów i siły roboczej, nie stanowią zagrożeń dla zachowania tożsamości narodowej?

Zapewne i w dziedzinie muzyki nie można się ustrzec wpływu mody i nowych stylów. Są one kreowane przez przemysł pop-kultury i kierują rozwój społeczeństw ku coraz większemu ujednoliceniu stylu życia. Coraz częściej przejeżdżając granice państw, trudno się zorientować, na terenie jakiego kraju jesteśmy, ponieważ architektura zabudowy europejskich miast i wsi staje się podobna, oparta jest bowiem na tych samych lub bliźniaczo podobnych wzorcach i katalogach. Podobnie jest w muzyce popularnej, Wydaje się jednak, że choć posługujemy się narzędziami wynalezionymi w innych krajach, bo dzięki nim łatwiej jest się porozumieć międzykulturowo, wciąż pozostajemy przywiązani do ojczystych kodów kulturowych i to one są często $w$ dalszym ciągu determinantą naszych wyborów i samookreśleń. Podobnie jest ze współczesną muzyką, która moim zdaniem, może wyrażać i kształtować tożsamość narodową, bywa też pomocna w czasach zagrożenia zewnętrznego, wewnętrznego, w czasach regularnej wojny, ale i w czasach pokoju. Kiedyś pielęgnowana w kościołach, w salkach katechetycznych, podczas ognisk drużyn harcerskich i różnorakich wspólnot kultywujących wartości patriotyczne i jednocześnie religijne, dziś w sposób oficjalny bywa wykonywana podczas uroczystości upamiętniających kolejne rocznice naszych zwycięstw w bitwach i wojnach, opiewa naszych bohaterów narodowych. Jest również coraz częściej obecna „na radośnie”, „na wesoło”, jak np. podczas meczów piłki nożnej, siatkówki bądź w tle skoków narciarskich - wszędzie tam, gdzie choćby chwilowe zgromadzenie rodaków stwarza możliwość poczucia się wspólnotą o tym samym pochodzeniu i dążeniu, wspólnotą będącą przekrojem wszystkich warstw społecznych zjednoczonych wobec jakiejś wspólnej idei mającej znamiona polskości. Do dziś w wielu rodzinach śpiewa się polskie pieśni przy biesiadnym stole, organizowane są wspólne „śpiewanki” czy to piosenek powstańczych w Warszawie, czy to pieśni legionowych z okazji kolejnych rocznic odzyskania niepodległości, czy wreszcie odbywa się 
wspólne kolędowanie nie tylko w kościołach czy podczas koncertów, ale także po nich lub nawet zamiast nich. Mimo nieuniknionych procesów uniwersalizujących, kosmopolityzacji, makdonaldyzacji, fascynacji odmiennością kulturową, wydaje się, że muzyka narodowa zawsze będzie miała szczególnie ważne miejsce w świadomości jednostek identyfikujących się z kulturą danego narodu, będzie jednym z jej kodów kulturowych. Rodzi się pytanie o granice przynależności, o jednoznaczne określenie, kim jestem i co jest moim punktem odniesienia w przypadku przyporządkowania rozstrzygającej tożsamości narodowej (Berger \& Zijderveld, 2010, s. 150).

Obok współczesnych bohaterów narodowych, ikon polskości z dziedziny sztuki, sportu, polityki, religii, czy też autorytetów świata nauki, niewątpliwie ambasadorkami polskości w sposób szczególny są polska pieśń i piosenka narodowa, będące wyrazem przynależności kulturowej i narodowej. W moim odczuciu pielęgnowanie dziedzictwa kulturowego poprzez upowszechnianie pieśni i piosenek patriotycznych jest odzwierciedleniem naszej tożsamości narodowej w aspekcie historycznym i współczesnym.

Chcemy się różnić. I właściwie trudno uniknąć skłonności, aby nie widzieć siebie w lepszym świetle, a "onych" w gorszym. Na przykład uważamy, że "oni" to nacjonaliści, a "my" patrioci, choć nasz patriotyzm przez innych może być postrzegany jako nacjonalizm. Utrwalanie narodowych wartości może prowadzić do utrwalania schematów, a nawet do ksenofobii. W sztuce to dość cienka granica.(...) - Sztuka może i powinna ułatwiać kontakt między ludźmi o innej mentalności, różnych społeczeństw, a także innych religii(Dziemidok, 2005).

\section{ROLA PIEŚNI I PIOSENEK W HISTORII POLSKI}

W historii Polski prześladowania z reguły umacniały tożsamość narodową, a tożsamość narodowa m.in. dzięki kulturze pozwalała przetrwać narodowi. Rola pieśni patriotycznej w historii Polski była ogromna. Kiedy nie było państwa polskiego, nie było polskich szkół, nie było sformalizowanych struktur ocalania polskości, była jednak rodzina, Kościół, gdzie kultywowane były tradycje narodowe i obrzędy charakterystyczne dla kultury polskiej, i była polska pieśń, która stała się międzypokoleniowym spoiwem, symbolem i wartością nadrzędną przekazywaną z pokolenia na pokolenie, śpiewana po polsku.

Co to znaczy polskie, co to znaczy nasze? Pieśni patriotyczne w moim przekonaniu są bardzo prostym w wyrazie symbolem naszej tożsamości narodowej. Pamiętajmy, że dziś, żyjąc od 25 lat w wolnym demokratycznym kraju, możemy nie doceniać wagi tych prostych w formie, lecz bardzo ważnych utworów. Okazuje się jednak, że w sytuacjach zagrożenia, w ucisku, w niewoli, udręce przypominamy sobie właśnie to, co nasze. Często bywają to słowa modlitwy lub pieśni, tych zasłyszanych od matki, kojących, uspokajających, dających nadzieję, po prostu rodzimych. Kiedy nikt i nic nam nie zagraża, nasze poczucie tożsamości narodowej jest „w uśpieniu”. Dopiero zewnętrzny lub wewnętrzny wróg uświadamia nam potrzebę manifestacyjnej identyfikacji, nawet za cenę krwi lub innych opresji. Wtedy słowa i dźwięki wracają, znajdują godne miejsce w sercach Polaków. Zadaniem utworów patriotycznych na przestrzeni dziejów było podtrzymywać na duchu, krzepić, pielęgnować okruchy polskości zaklęte w dźwiękach i słowach, w pieśniach towarzyszących obrzędom, wszechobecnych w dawnym codziennym życiu Polaków. Utwory te stwarzają również uczucie dumy narodowej, identyfikację z bohaterami tamtych dni, dzięki którym dziś żyjemy w wolnej Polsce. Muzyka Chopina, Kilara czy Dębskiego prze- 
mawia do nas językiem uniwersalnym, językiem bez słów, a jednak tak bardzo polskim, rzewnym, romantycznym, jednocześnie podniosłym, dostojnym, z całą pewnością - niebanalnym (Śmiechowski, 1993, s. 164).

Oto, jak o Chopinie pisał wybitny francuski krytyk muzyczny Camille Bellaigue:

Nie znam muzyka, który by więcej był patriotą niż on. Chopin jest Polakiem bardziej niż Francuz był kiedykolwiek Francuzem, Włoch - Włochem, a Niemiec - Niemcem. Jest Polakiem, nic tylko Polakiem, a z tego wyniszczonego, zgnębionego kraju polskiego wyłania się jego muzyka, jak nieśmiertelna jego dusza (Śmiechowski, 1993, s. 164).

Język jest jak stygmat, kiedy słychać wciąż pierwotny akcent obcokrajowca nawet po wielu latach spędzonych za granicą. Usiłujemy głębię uczuć wyrazić w obcym języku, ale okazuje się to bardzo trudne lub wręcz niemożliwe. Szczególnie wyraźne staje się to piętno w sytuacji zagrożenia, wtedy kiedy tylko słowa zasłyszane od matki potrafią wyrazić miłość, szczęście, czy wreszcie nieopisany ból. Icchak Kacenelson w obozie w Vittel przez 10 miesięcy napisał największe dzieło swojego życia właśnie w swym języku narodowym, w jidysz. Stworzył poemat Pieśń o zamordowanym żydowskim narodzie, ukrył go w butelce i zakopał w ziemi. Po wojnie utwór został odnaleziony. Było to sposobem Kacenelsona na przetrwanie i dodanie nadziei kolejnym pokoleniom, że nawet w największym uciśnieniu nadzieja umiera ostatnia, a wyrażona może być ona jedynie w języku ojczystym, intuicyjnym, często nieprzetłumaczalnym na inne języki.

Niektórzy pisarze, poeci i kompozytorzy mieli poczucie obowiązku pisania o Polsce i polskości, szczególnie ci, którym przyszło żyć w czasach, kiedy nasza narodowa tożsamość była zagrożona, kiedy Polski przez 123 lata nie było na mapach świata. Pod okupacją, pod zaborami okazywało się, że to właśnie m.in. dzięki muzyce udawało się przetrwać, przekazać z pieśnią kolejnym pokoleniom polskie tradycje i obyczaje. Były one zapisem rzeczywistości, obrzędów. Stały się „dokumentem tamtych czasów” (Nowaczewski, 2010) i jedynym sposobem na wniknięcie dziś w tamtą rzeczywistość, muzyka bowiem potrafi oddać nastrój panujący wówczas. To ona wyraża emocje, nastroje i charakter danej grupy etnicznej czy narodowej. Wyrażanie siebie, samookreślenie w epoce piśmiennej przychodzi łatwiej, możliwość wymiany myśli, a przede wszystkim możliwość zapisu i powielenia kopii tekstu jest bezcenna, pamięć ludzka bywa bowiem ulotna i zawodna. Od wieków jednak były i na to sposoby. Zdecydowanie łatwiej zapamiętać utwór rytmizowany, rymowany wiersz, a tym bardziej melodyjny - np. w formie piosenki. To właśnie dzięki pieśniom i zawartym w ich strofach zapisom wiemy, jaka była nasza historia, jacy byli nasi przodkowie, jakie były nastroje i problemy, i wreszcie, jaki duch panował dawniej. Poprzez to, co nam bliskie, zasłyszane od dziadków, owiane legendą - niezauważalnie dla nas samych nasiąkamy tym wszystkim, oswajamy się z tym, z czasem coraz bardziej lubimy i wreszcie uświadamiamy sobie, że jest to „nasze”, „swojskie”, identyfikujemy się z tym. Wyrazem tego może być tęsknota za polskością, za polską mową, za muzyką polską, za bliskimi dźwiękami, które nas uspokajają, koją, dają poczucie zrozumienia i bezpieczeństwa. To piosenki i przyśpiewki matki, dźwięki intuicyjnie rozpoznawane nawet z daleka po samej intonacji, to po prostu melodie i dźwięki oswojone. Można doświadczyć takich uczuć na przykład podczas dłuższego pobytu na emigracji. Tęskni się do polskiego opłatka, Wigilii, kolęd, śniegu, zapachu świąt, do niepowtarzalnego i specyficznego nastroju polskich świąt Bożego Narodzenia. Owa swojskość, oswojenie, niepowtarzalność i specyficzność poskładana z wielu różnorodnych elementów na płaszczyźnie dźwięków i obrazów, zapachów i smaków, wreszcie symboli tworzy pełen obraz zmysłowo i pozazmysłowo uświadamianych i nieuświadomionych atrybutów polskości, rosyjsko- 
ści, niemieckości, angielskości, australijskości lub japońskości, czy szerzej - europejskości bądź afrykańskości, czy azjatyckości.

W przypadku muzyki instrumentalnej pozbawionej tekstu sprawa jest bardziej skomplikowana. Muzyka instrumentalna jest bardziej intuicyjna, impresyjna, wyobrażeniowa, często trudno zwerbalizować jej treść. Jak zatem można za jej pomocą wyrażać i w dodatku kształtować tożsamość narodową? Muzyka, jak żadna inna ze sztuk, potrafi oddać panujący nastrój, wywołać określone emocje, poruszyć struny naszej duszy. Kiedy przyjdzie czas zadumy nad naszą tożsamością, bezwiednie mogą pojawić się w naszej wyobraźni dźwięki, melodie, harmonia, wspomnienia z nimi związane, nasze wyobrażenia o historiach w nich zawartych, nasze emocje wywołane jakimś motywem - dla innych nacji niezrozumiałym i nieczytelnym. Czy można zidentyfikować źródło owej „swojskości”, charakterystycznej tylko dla określonej nacji? Próbą odkodowania tego zjawiska była analiza przeprowadzona prawie 200 lat temu przez Józefa Elsnera.

M. Demska-Trębacz zauważa spostrzeżenia Elsnera z „Rozprawy o metryczności i rytmiczności języka polskiego, szczególniej o wierszach polskich we względzie metrycznym" Warszawa 1818:

(...) Józef Elsner poddał analizie zjawiska rytmiczne i melodyczne języka polskiego. Znalazł w nich swoiste właściwości w rytmach z akcentem na przedostatniej sylabie - w końcówkach, jak w polonezie. (...) Dzięki dociekaniom nad metryką języka Elsner ochronił mowę polską przed deformacją w sytuacji, gdy słowo spoczywa w rękach kompozytorów. (Demska-Trębacz, 2004, s. 253).

Dzięki wnikliwej analizie słów Józefa Elsnera możemy dziś uzmysłowić sobie wpływ mowy polskiej na muzykę polską. Może to właśnie jest kluczem do odpowiedzi na pytanie, czy rzeczywiście można przypisać muzyce instrumentalnej jej charakter narodowy i czy wreszcie może ona wyrażać i kształtować tożsamość narodową?

To co Chopina czyni w porównaniu do innych interesującym i co go najbardziej od innych wyodrębnia, to jego niezwykle zdecydowana cecha narodowości, a mianowicie polskość. Gdyby samowładny monarcha północy (tj. car Mikołaj I) wiedział, jak niebezpieczny wróg mu grozi w dziełach Chopina, w pełnych prostoty jego mazurkach, zabronitby w swym państwie wykonywania tych utworów: są to armaty ukryte wśród kwiatów (Czartkowski \& Jeżewska, 1959, s. 281).

Wiedzieli o tym Niemcy sto lat później: „Gdy w 1939 r. w okupowanej Warszawie hitlerowski gubernator rozpoczął swe urzędowanie, jednym z pierwszych jego zarządzeń było zdemolowanie pomnika Fryderyka Chopina w Łazienkach" (Czartkowski \& Jeżewska, 1959, s. 263).

W czym tkwi tajemnica polskości muzyki Chopina? Już mu współcześni w 1849 roku próbowali znaleźć odpowiedź na to pytanie i odnaleźć sens zaklęty w dźwiękach wydobywanych z klawiszy fortepianu.

(...) Chopin i naszego mazura wyniósł do wysokości utworu sztuki, nie zatarłszy w nim odrębnego charakteru tańca, zrobił go wiernym odbiciem teraźniejszego odbicia polskiej duszy przez połączenie bolejących tonów z wesołymi niejako, radości z chwilowego powodzenia - z zawiedzioną nadzieją. Dlatego mazurki Chopina osnute na wiejskich melodiach są wyłącznie polską muzyką; obcy naród ich piękności i znaczenia zrozumieć nie zdoła(Czartkowski \& Jeżewska, 1959, s. 594 - za Antonim Woyciechowskim, poznańska "Gazeta Polska" 11 i 12 listopada 1849).

Zdaniem tego autora "nie zdoła”, jednak okazało się, że naród japoński zafascynował się muzyką polską Chopina. Bo właśnie o owo znaczenie tu chodzi - o kontekst kulturo- 
wy, o mentalność i szereg kodów kulturowych ukrytych w rzewnych dźwiękach, które potrafią zarówno wzruszyć, przywołać wspomnienia, jak i dźwiękach monumentalnych, które podbudowują poczucie polskości. Jak bowiem słusznie zauważył Lew Tołstoj, "Muzyka jest stenografią uczuć" i właśnie w tych uczuciach, które ona wywołuje u słuchacza, można odnaleźć charakter, również narodowy.

Jak rozpoznać styl narodowy? Czym on się on charakteryzuje, jak go zdefiniować?

Mówiąc o stylu narodowym, nie można pominąć zależności: język - muzyka. Ludowa i narodowa muzyka wokalna wiąże poetycką wypowiedź słowną z wypowiedzią muzyczną. Wpływ języka (różnych narodów) na rodzimą muzykę jest wielostronny i udowodniony empirycznie (Przychodzińska-Kaciczak, 1984, s. 289).

Istnieje jednak niebezpieczeństwo w charakteryzowaniu poszczególnych stylów narodowych oparte najczęściej wyłącznie na panujących stereotypach, o których pisze Antonina Kłoskowska (1996, s. 94). Sądzę, że dotyczy to również do muzyki.

Biorąc pod uwagę dramatyczną sytuację narodu polskiego w okresie zaborów, oczywistą staje się rola pieśni i literatury podtrzymujących polskość.

Pieśń artystyczną wspólnoty bez państwa determinował bieg wydarzeń. Stawała się ona orężem w walce, jak „Wojak" Chopina, czy "Stary kapral" Moniuszki (...). Te śpiewy, które podążyły tropami Kurpińskiego, pełne były funkcji apelatywnej, co dokumentują choćby pieśni powstańcze: „Bracia, do bitwy nadszedł czas”, "Hej kto Polak na bagnety”. Równolegle były w pieśni uwzględniane wątki refleksyjne, na przykład symbole żałoby narodowej, jak w "Czarnej sukience" Żeleńskiego. (Demska-Trębacz, 2004, ss. 256).

Oprócz charakterystycznych polskich melodii istotną rolę pełniły słowa tych pieśni. Skoro źródło muzyki jest, być może, także w języku, to w tej sytuacji muzyka narodowa byłaby niejako dopełnieniem i uzupełnieniem słowa, tam gdzie, jak mawiał Stefan Krzywoszewski, „słowo nie starczy”. Być może to właśnie rozwieje wątpliwości, czy język muzyki nie jest zbyt uniwersalny i abstrakcyjny w odróżnieniu od form twórczości posługujących się stowami.

Pokrewieństwo muzyki z mową bywa uderzające. Prowokujące wręcz jest pytanie o to, co było najpierw: muzyka, czy mowa? A może mają one wspólne źródło, z którego wyodrębnity się z czasem jako dwa sposoby porozumiewania się przy pomocy dźwięków? Jeden - język służy do nadawania nazw przedmiotom, opisywania czynności i zjawisk; w potocznym odczuciu jest on konkretny. Drugi - muzyka - pozwala wyrażać uczucia i tworzyć nastroje. Dziś niektóre związki między nimi są co najmniej tajemnicze i ów wspólny początek mogą sugerować. Co ciekawe, dobrze wiedzą o tym lekarze. Są bowiem chorzy, którzy nie mogą mówić, ale mogą śpiewać (Gwizdalanka, 2012).

\section{ROLA MUZYKI W KONTEKŚCIE PAMIĘCI NARODOWEJ}

„Śpiewam, więc jestem” - takiej trawestacji znanej sentencji Kartezjusza „Myślę, więc jestem”, („Cogito, ergo sum”) dokonał Wacław Panek, który pisze:

Wspólny śpiew i wspólne, znane wszystkim pieśni - to chyba najmocniejszy emocjonalny znak tożsamości danej wspólnoty (np. harcerzy, żeglarzy, rolników) lub całego narodu. Śpiewam ze wszystkimi wokół hymn harcerski "Wszystko co nasze Polsce oddamy" i czuję, że jestem zarówno cząstką tej wspólnoty harcerskiej, jak i cząstką Polski (Panek, 1999, s. 170). 
W. Panek przytacza słowa Jana Kasprowicza zawarte w wierszu "Rzadko na moich wargach": „pieśń ojczyzny pełna”.

Bowiem nasza pieśń (zwłaszcza pieśni hymniczne) jest gatunkiem, który najpowszechniej i najintensywniej służy kształtowaniu poczucia polskości. Bo czyż jest jakiś obraz, dzieło literackie (łącznie z "Panem Tadeuszem") czy architektoniczne (łącznie z Wawelem) - które by znało w każdym pokoleniu tylu Polaków, ilu zna i śpiewa "Mazurka Dąbrowskiego", „Boże, coś Polske, czy "Rotę (Panek, 1999, s. 170).

Wacław Pacek ma rację. Śpiewam, więc jestem i przez śpiew wyrażam to, kim jestem i jakie wartości są dla mnie ważne. Weźmy na przykład kolędy polskie, rekordowo liczne na tle pieśni bożonarodzeniowych innych nacji, opiewające cud narodzenia, ale często wykorzystywane jako baza muzyczna do przemycania treści patriotycznych. Bardzo częstą praktyką było układanie do melodii znanych kolęd nowych, adekwatnych do sytuacji geopolitycznej słów. Ich rozpowszechnianie było wtedy dużo łatwiejsze, a zapamiętanie bardziej przystępne. Trzeba tu wymienić Hymn do miłości ojczyzny lgnacego Krasickiego, napisany w 1772 r., do którego muzykę stworzyło wielu kompozytorów; najbardziej rozpowszechniła się wersja skomponowana w 1831 r. przez Wojciecha Sowińskiego i ten utwór od ponad dwustu lat jest jedną z naszych najważniejszych pieśni narodowych. Bardzo wartościowe są spisane przez Oskara Kolberga, unikatowe w skali światowej, pieśni ludowe. Dzieło Kolberga Lud. Jego zwyczaje, sposób życia, mowa, podania, przysłowia, obrzędy, gusła, zabawy, pieśni, muzyka i tańce obejmuje kilkadziesiąt tomów pieśni ludowych, bajek i baśni, podań i legend, wierzeń i zwyczajów ludowych, które stworzyły podwaliny badań nad polską kulturą ludową i zainicjowały powstanie nowej dziedziny nauki - etnografii („Oskar Kolberg”, b.d.). Podobnie ważne są Śpiewniki domowe Stanisława Moniuszki - niezwykle wartościowy zbiór ponad 300 pieśni i piosenek stworzonych przez zawodowego kompozytora, a stanowiących przez całe stulecie podstawowy repertuar domowego muzykowania. Ważną rolę odegrały opery Moniuszki, a w szczególności Straszny dwór, gdzie znalazła się „kwintesencja kodów narodowych, tak znaczących, jak wielka metafora Ojczyzny - Matki w "Arii z kurantem”, czy symbol rodzinnego gniazda, które trzeba strzec - szlachecki dwór. To Miecznik śpiewa w Strasznym dworze: "Mieć w miłości kraj ojczysty (...) na skinienie oddać krew" - wezwanie do walki podobne jak w polskich pieśniach" (Demska-Trębacz, 2004, s. 258).

Kontynuatorem takiego ocalania od zapomnienia polskiej pieśni i obyczajowości, a także komponowania w tym stylu, był Tadeusz Sygietyński, założyciel Zespołu Pieśni i Tańca "Mazowsze”. Jerzy Waldorff, wybitny krytyk muzyczny, nazwał „Mazowsze”

perłą w koronie Rzeczypospolitej. To stwierdzenie najpełniej oddaje rangę i wartość Zespołu, który od ponad 60 lat porywa publiczność na całym świecie, pełniąc zaszczytną funkcję Ambasadora Polskiej Kultury." (...) Tadeusz Sygietyński, wybitny kompozytor i miłośnik folkloru oraz Mira Zimińska-Sygietyńska, aktorka przedwojennej sceny, w ruinach bombardowanej Warszawy przyrzekli sobie, że jeśli przeżyją wojnę, założą zespół. (...) Zimińska porzuciła karierę aktorki i zajęła się sprawami organizacyjnymi. Sygietyński komponował w oparciu o oryginalne ludowe pieśni. Przetrząsali wiejskie chaty. Zimińska w poszukiwaniu "babcinych" strojów, Sygietyński w poszukiwaniu uzdolnionej młodzieży..(...) "Mazowsze" należy do największych na świecie zespołów artystycznych, sięgających do bogactwa narodowych tańców, piosenek, przyśpiewek i obyczajów. Nazwa zespołu wywodzi się od centralnego regionu Polski - Mazowsza, jednak repertuar "Mazowsza" szybko rozszerzył się o folklor innych regionów. Dziś w dorobku zespołu znajdują się opracowania sceniczne 42 z nich. („Mazowsze”, b.d.)

Szczególny stosunek do muzyki ludowej miał Karol Szymanowski, którego twórczość była zawsze oparta na polskiej tradycji muzycznej, szczególnie ta skomponowana w ostat- 
nich latach jego życia, kiedy sięgat w swoich pomysłach muzycznych do skarbnicy sztuki ludowej, do muzyki góralskiej i kurpiowskiej. Sam Szymanowski tak wyrażał swój stosunek do muzyki ludowej:

Folklor ma dla mnie jedynie znaczenie czynnika zapładniającego. (...) Charakter narodowy kompozytora nie polega na cytatach folkloru, czego najwspanialszym przykładem jest twórczość Chopina („Tatry | Karol Szymanowski”, b.d.).

Największą popularnością cieszą się jednak utwory związane z ważnymi wydarzeniami historycznymi, które zostają w pamięci potomnych na długo. Posłużę się konkretnymi przykładami utworów patriotycznych wciąż żywych w pamięci współczesnych Polaków, jak choćby pieśni z czasów powstania styczniowego: "Jak to na wojence ładnie”, czy też piosenki z czasów I wojny światowej - jak śpiewana do dziś - „Pierwsza Kadrowa”, napisana przez 19-letniego żołnierza I Kompanii Kadrowej Tadeusza Ostrowskiego, do której melodia zaczerpnięta została z popularnej piosenki ludowej "Siwa gąska siwa, po Dunaju pływa”, "Rapsod o Kuli - Lisie”, "Wojenko wojenko, cóżeś ty za pani”, „Rozkwitają pąki białych róż”, „Piechota” („Maszerują strzelcy”) czy „Pierwsza brygada”, którą marszatek Józef Piłsudski nazwał "najdumniejszą pieśnią, jaką kiedykolwiek Polska stworzyła”. Szczególne miejsce w panteonie pieśni patriotycznych ma z pewnością pieśń „Orlątko Iwowskie" do słów Artura Oppmana, do muzyki O. Emskiego, powstała w 1918 r. Pochodziła ona z widowiska jasełkowego „Baśń o szopce”, a opiewała losy młodych polskich chłopców walczących z Ukraińcami w obronie Lwowa. Łatwo odnaleźć ślady wojny w tekstach i muzyce z czasów II wojny światowej, czego przykładami są: partyzancka "Dziś do ciebie przyjść nie moge", "Czerwone maki na Monte Cassino”, a w szczególności piosenki powstańcze z barykad walczącej Warszawy: "Marsz Mokotowa”, „Pałacyk Michla", "Mała dziewczynka z AK" i inne.

Można sformułować tezę, że narodowe pieśni polskie w czasach zagłady, okupacji i uciemiężenia były, są i będą spoiwem łączącym kolejne pokolenia Polaków jako istotny element ich poczucia tożsamości narodowej, odrębności narodowej.

Jak zauważa Wacław Panek, autor podręcznika Świat muzyki, można zaobserwować pewną niezwykłą prawidłowość:

bez względu na warunki polityczne czy miejsce walki żołnierza polskiego, bez względu na czas historyczny tej walki (np. "My pierwsza brygada" była śpiewana podczas drugiej wojny światowej w I Dywizji im. Tadeusza Kościuszki w ZSRR z nowym tekstem jako Hymn I Dywizji), wszystkich łączyły melodie pieśni. Zmieniano teksty, dopisywano nazwiska aktualnych dowódców, przesuwano akcenty z jednych symboli na inne, lecz melodie trwały i wskazywały łączność między wszystkimi Polakami (Panek, 1999, s. 170).

To właśnie melodia stawała się wspólnym mianownikiem w równaniach o polskości. Inny przykład - piosenka "Czerwonych Gitar” z 1968 r., "Biały krzyż” do słów Janusza Kondratowicza i Krzysztofa Klenczona, wykonywana jest z powodzeniem współcześnie. Opowiada o symbolicznym polskim białym krzyżu stawianym na żołnierskich, partyzanckich mogiłach. Na uwagę zasługuje „Bema pamięci żałobny rapsod” Cypriana Kamila Norwida, który zainspirował Czesława Niemena do skomponowania pełnego ekspresji utworu, wykonywanego do dziś. Innym przykładem są wykonane po raz pierwszy w wersji muzycznej 27 listopada 2012 r. podczas koncertu w Muzeum Powstania Warszawskiego utwory powstańca walczącej Warszawy Józefa Szczepańskiego, pseudonim "Ziutek”, autora takich powstańczych hitów jak „Pałacyk Michla” czy "Chłopcy silni jak stal”, do którego wierszy dodano melodie skomponowane przez twórców młodego pokolenia 
XXI w. "Dziś idę walczyć - Mamo”, czy "Już nie wróci twój chłopiec - dziewczyno”, „A gdy będzie już po wojnie”, czy też zakazana przez blisko 50 lat „Czerwona zaraza” w wersji rockowej. Podobnie, wiersze Krzysztofa Kamila Baczyńskiego są interpretowane na nowo, współcześnie, jak choćby propozycja wykonania popowego jednego z jego wierszy "Których nam nikt nie wynagrodzi” przez Grażynę Łobaszewską. A z kolei w PRL wspomnijmy piosenki „Żeby Polska była Polską” Jana Pietrzaka, z muzyką Włodzimierza Korcza, albo "Skrzydła”, do słów Ernesta Brylla i z muzyką Włodzimierza Korcza, czy "Ojczyzna" ks. Stefana Ceberka, "Zapamiętaj tamten wrzesień" do słów Wojciecha Kejnego i z muzyką Bolesława Szulii, wreszcie „Póki Polska żyje w nas” do słów Wojciecha Kejnego z muzyką Włodzimierza Korcza. Czym są dziś te utwory? Strażnikami naszej tożsamości narodowej? Wierzę, że tak właśnie jest. Warto przypomnieć niezapomnianego barda Jacka Kaczmarskiego, o którym prezydent Rzeczypospolitej Polskiej Bronisław Komorowski mówił:

Trzeba utrwalać pamięć o tym dramatycznym momencie wprowadzenia stanu wojennego, o 13 grudnia, ale nie tylko pamiętać o czołgach na ulicach miast polskich, także pamięć o krwi przelanej w imię wolności. Trzeba również budować w nas dumę z faktu, że od tak trudnego etapu naszej historii przeszliśmy do etapów zwycięstwa i zabudowywania polskiej wolności. W ramach naszej pamięci jest i powinno być miejsce dla Jacka Kaczmarskiego, dla Jego twórczości, dla słów Jego piosenek, które nas wtedy i dzisiaj umacniają w przekonaniu, że to była słuszna, dobra i zwycięska polska droga do wolności. Pamiętam sam takie szczególne koncerty, kiedy spotykaliśmy się w różnych mieszaninach warszawskich, aby słuchać Jacka Kaczmarskiego, który siedział na jakimś materacu, grał na gitarze i było nam bardzo dobrze razem - w gronie ludzi, którzy wierzyli, ze te złe mury runą. I runęły. I dzisiaj myślę o Jacku Kaczmarskim jako o tym, który miał ten swój wielki udział w budowaniu naszej nadziei i naszej determinacji w walce o to, aby mury runęły i Polska była krajem wolnym (Komorowski, 2014).

Taką rolę pełnią i pełniły pieśni zaangażowane, jak o nich mawiał sam Kaczmarski. „Piosenka to nie jest publicystyka polityczna, tylko próba ukazania jakiegoś zjawiska w jego wymiarze ludzkim, czyli z natury rzeczy niejednoznacznym, wielowarstwowym" (Kaczmarski, 2014, s. 2).

Dziś rolę podobną do wyżej opisanej odgrywa muzyka filmowa - pełni ona funkcję ilustracyjną. Tak jest w przypadku muzyki Wojciecha Kilara stworzonej do filmu „Pan Tadeusz", w szczególności zyskującego sobie więlką popularność poloneza z filmu „Pan Tadeusz", czy też góralskiego „Krzesanego” bądź „Kościelca”. Michał Lorenc skomponował muzyke do filmu "Różyczka”, z jego ścieżki dźwiękowej szczególnego znaczenia nabrał utwór "Wyjazd z Polski", który został wykorzystany do większości relacji TVP z wydarzeń związanych z katastrofą smoleńską. Z kolei wiersz Adama Asnyka „Miejcie nadzieję nie tę lichą marną", zilustrowany muzyką Zbigniewa Preisnera, jest także wykonywany jako utwór symboliczny, podobnie jak „Rota” Marii Konopnickiej, mimo oficjalnego stanowiska kompozytora muzyki do wspomnianego wiersza Asnyka, by nie wykonywać go podczas na przykład uroczystości upamiętniających katastrofę smoleńską jego muzyka do tego wiersza, jak wiele innych utworów nacechowanych narodowo, stała się jak gdyby własnością wszystkich Polaków i wydaje mi się, że niosąc ze sobą określone treści i cytaty muzyczne, może być wykorzystywana do różnych celów. To właśnie melodyka i zbudowany przez nią nastrój determinuje charakter i okoliczności ich wykonywania na żywo i odtwarzania.

Nawet polskie prawo autorskie zajmuje się tym zagadnieniem, umożliwiając wykonawcom bezpłatne korzystanie z dóbr kultury narodowej, jakimi są pieśni patriotyczne oraz ludowe, wiąże się to z wymierną korzyścią zwolnienia z opłat ZAiKS-u po złożeniu stosow- 
nego podania skierowanego do właściwego miejscowo organu tej instytucji („Dozwolony użytek utworów", b.d.).

Nie sposób nie wspomnieć o niebagatelnej roli pieśni religijnych w Polsce, które przez wieki państwowości polskiej, ale także, a może przede wszystkim, podczas długich lat jej utraty i sukcesywnej rusyfikacji i germanizacji, dwóch wojen światowych i epoki komunizmu stały na straży wartości patriotycznych, a sam Kościół był niejednokrotnie bezpieczną przystanią, w której można i trzeba było otwarcie wyrażać swoją przynależność narodową. Wiązało się to również z tym, że katolicyzm wówczas był - i wciąż bywa - identyfikowany z polskością, zaś zaborcy wyznawali na ogół protestantyzm lub prawosławie. Paradoksalne więc określanie Polak - katolik było „zasługą" nie tylko Kościoła katolickiego, ale i sytuacja ta była „zasługą" zaborców. Polskie pieśni religijne śpiewane były nie tylko w świątyniach podczas nabożeństw, ale również w polskich domach, podczas wspólnych spotkań rodzinnych i sąsiedzkich, a poprzez to kojarzone były z rodzimością mowy polskiej, zaś przekazywane w ich treści wartości szły w parze z duchem patriotyzmu.

Cechą wspólną tych polskich pieśni i piosenek jest ich łatwa przyswajalność melodyczno-rytmiczna, a w warstwie tekstowej odnoszenie się do symboliki typowo polskiej, akcentowanie charakterystycznych polskich cech narodowych, dziarskość i zawadiackość, ale także zaduma, refleksja i romantyczna wręcz melancholia - będące odzwierciedleniem duszy narodu polskiego. Piosenki mają tę właściwość, że są łatwo zapamiętywane i tym samym szybko się rozprzestrzeniają.

W piosenkach słowo i muzyka osiągają równowagę: jedna sylaba - jeden dźwięk. Wiele piosenek po rozłożeniu na te dwie części - słowa i melodia - może zresztą rozczarować: melodia mało oryginalna, słowa niezybyt mądre - ale razem tworzą coś, co zapada w pamięć czasem i na wiele pokoleń. I choć niektórzy ludzie lepiej zapamiętują melodie, inni tekst, to wszyscy zdecydowanie lepiej zapamiętują tekst razem z melodią niż same słowa albo samą melodię (Gwizdalanka, 2012).

\section{ZAKOŃCZENIE}

Artykuł przybliża znaczenie muzyki dla ugruntowywania się i umacniania poczucia tożsamości narodowej czy też regionalnej zbiorowości społeczno-kulturowej. Muzyka jest jednym z istotnych czynników określających naszą narodowość, wszak mówi się o melodyjności poszczególnych języków obcych. Przywiązanie do pieśni znanych w określonych kręgach kulturowych to nie tylko wyraz potrzeb wyrażania siebie poprzez kreację muzyczną, chęć integracji z grupą, ale także budowanie i umacnianie poczucia tożsamości: jednostkowej, społecznej, wspólnotowej, regionalnej i narodowej. Muzyka współczesna w swoich różnych odmianach ulega przeobrażeniom, ewoluuje, co jest naturalną koleją rzeczy w rozwoju kulturowo-cywilizacyjnym ludzkości. Niemniej jednak chęć zachowywania tradycji muzycznych i powracania do nich jest oznaką ogromnego szacunku do wytworów sztuki i obcowania ze znanymi, nieprzemijającymi wartościami muzycznymi, które zaświadczają o naszym bogactwie duchowym i ukonstytuowaniu tożsamościowym.

Jakie będą te kolejne - nasze, polskie pieśni? To w dużej mierze zależy od okoliczności, w jakich przyjdzie nam żyć, od naszego poczucia bezpieczeństwa lub zagrożenia, naszego poczucia dumy narodowej bądź wstydu, od poczucia wyjątkowości lub nijakości na tle innych lub asymilowania tego, co nie powinno być zasymilowane, lecz pielęgnowa- 
ne za pomocą muzyki i słowa. A czy będą też kolejni nasyceni polskością kompozytorzy, którzy bez słów potrafią oddać nastrój i ducha naszej ojczyzny? Czy globalizacja dosięgnie muzyki, czy też wręcz odwrotnie spowoduje powrót do etnicznych symboli muzycznych? Czy grozi nam zangielszczenie, zuniwersalizowane brzmienie? Czy zyskanie niepodległości nie pomniejsza roli pieśni patriotycznej? Odpowiedź na te pytania przyniesie przyszłość. Warto mieć jednak świadomość własnej odmienności i pielęgnować dziedzictwo przodków dla kolejnych pokoleń. Maria Janion zauważa: „Profesor Antonina Kłoskowska słusznie zwraca uwagę, że to co wypadnie z kanonu szkolnego, wypadnie ze świadomości narodu i że w ten sposób naród stanie się inny" (Janion, 2000, s. 257). Dobrze byłoby zadbać o to, by w zestawie obowiązkowych utworów muzycznych poszczególnych narodów znalazły się te, które stanowią o ich odrębności i tożsamości, opowiadają ich historię i odwołują się do ich bohaterów narodowych. Ważną rolą rodziców i nauczycieli jest pielęgnowanie odmienności narodowej, wyrażanej między innymi poprzez wspólne śpiewanie polskich pieśni patriotycznych.

\section{BIBLIOGRAFIA}

Berger, P. L. (1988). Zaproszenie do socjologii. (J. Stawiński, Tłum.). Warszawa: Państwowe Wydawnictwo Naukowe.

Berger, P. L., \& Zijderveld, A. C. (2010). Pochwała wątpliwości: jak mieć przekonania i nie stać się fanatykiem. (S. Baranowski, Tłum.). Kraków: Wydawnictwo vis-à-vis.

Burszta, W. J. (2004). Różnorodność i tożsamość: antropologia jako kulturowa refleksyjność. Poznań: Wydawnictwo Poznańskie.

Czartkowski, A., \& Jeżewska, Z. (Oprac.). (1959). Chopin żywy w swoich listach i w oczach wspótczesnych. Warszawa: Państwowy Instytut Wydawniczy.

Demska-Trębacz, M. (2004). Rodzimość i europejskość w muzyce polskiej XIX i XX w. W M. Koźmiński (Red.), Cywilizacja europejska: wykłady i eseje (ss. 249-265). Warszawa: Wydawnictwo Naukowe Scholar/ Collegium Civitas Press.

Dozwolony użytek autorów. (b.d.). Pobrano 22 lipca 2014, z http://www.zaiks.org. pl/142,87,dozwolony_uzytek_utworow

Dziemidok, B. (2001). O potrzebie tożsamości narodowej, nacjonalizmie oraz integracyjnej i dezintegracyjnej roli artystycznych środdków przekazu w jednoczeniu Europy. W B. Dziemidok (Red.), Integracyjna i dezintegracyjna rola artystycznych środków przekazu w kształtowaniu tożsamości narodowej i jednoczeniu Europy. Gdańsk: Wydawnictwo Uniwersytetu Gdańskiego.

Dziemidok, B. (2005, marzec 31). Filozofowie się zdarzają. Biuletyn Ministra Nauki i Szkolnictwa Wyższego. Pobrano 22 lipca 2014, z http://www.sprawynauki.waw. $\mathrm{pl} /$ ?section=article\&art_id $=1667$

Dziemidok, B. (2008). Tożsamość narodowa a nacjonalizm w epoce globalizacji. W B. Szklarski (Red.), Mity, symbole i rytuaty we wspótczesnej polityce: szkice z antropologii polityki (ss. 139-152). Warszawa: Wydawnictwo Naukowe Scholar, Instytut Studiów Politycznych PAN.

Gwizdalanka, D. (2012). Magia muzyki. Muzyka a słowo. Wychowanie Muzyczne, (5). Pobrano 22 lipca 2014, z http://www.wychmuz.pl/artykul_ar_37.html

Janion, M. (2000). Do Europy tak, ale razem z naszymi umartymi. Warszawa: Wydawnictwo Sic! 
Kaczmarski, J. (2014, maj 31). Wywiad z 19 listopada 1999 r. udzielony Annie Erecińskiej. Gazeta Wyborcza, dodatek 25 lat wolności, s. 2.

Kłoskowska, A. (1996). Kultury narodowe u korzeni. Warszawa: PWN.

Komorowski, B. (2014, maj 31). Przed emisją koncertu „Wasz Kaczmarski”, TVP2. Gazeta Wyborcza, dodatek 25 lat wolności, s. 1.

Mazowsze. (b.d.). Pobrano 22 lipca 2014, z http://mazowsze.waw.pl/sub,pl,mazowsze--historia.html

Meyer, L. B. (1974). Emocja i znaczenie w muzyce. Kraków: Polskie Wydawnictwo Muzyczne.

Nowaczewski, R. (2010, sierpień 1). Bohaterom Powstania Warszawskiego - Strażacy. Plac Zamkowy, Warszawa, mazowieckie.

Oleś, P. K. (2008). O różnych rodzajach tożsamości oraz ich stałości i zmianie. W P. K. Oleś \& A. Batory (Red.), Tożsamość i jej przemiany a kultura (ss. 41-84). Lublin: Wydawnictwo Katolickiego Uniwersytetu Lubelskiego.

Oskar Kolberg. (b.d.). Pobrano 22 lipca 2014, z http://www.oskarkolberg.pl/index.php/site/ dziela

Panek, W. (1999). Świat muzyki: podreccznik klasy 1-3 Gimnazjum. Warszawa: Wydawnictwo Szkolne i Pedagogiczne S.A.

Przychodzińska-Kaciczak, M. (1984). Zrozumieć muzykę. Warszawa: Nasza Księgarnia.

Szacki, J. (2004). O tożsamości (zwłaszcza narodowej). Kultura i Społeczeństwo, 48(3/ lipiec-wrzesień), 9-40.

Śmiechowski, B. (1993). Z muzyką przez wieki i kraje (Historia Muzyki). Warszawa: Polski Dom Wydawniczy Sp. z o.o.

Tatry | Karol Szymanowski. (b.d.). Pobrano z http://www.karolszymanowski.pl/inspiracje/ inspiracje-folklorystyczne/tatry/ 